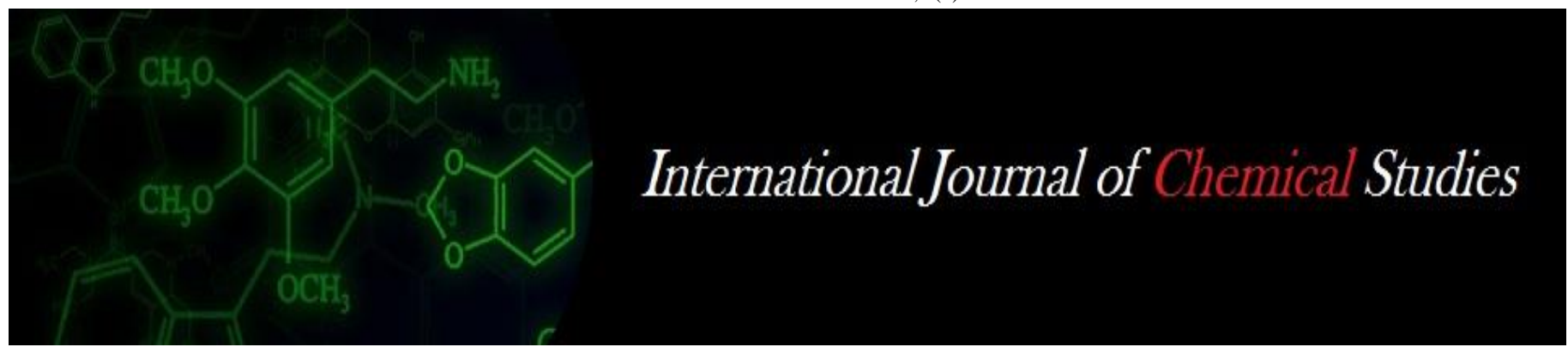

P-ISSN: 2349-8528

E-ISSN: 2321-4902

www.chemijournal.com

IJCS 2020; 8(4): 3593-3596

(C) 2020 IJCS

Received: 25-05-2020

Accepted: 30-06-2020

\section{RS Marbate}

P.G. Students, Agronomy

Section, College of Agriculture,

Nagpur, Maharashtra, India

\section{AL Uparkar}

P.G. Students, Agronomy

Section, College of Agriculture,

Nagpur, Maharashtra, India

\section{RJ Choudhari}

P.G. Student, Agricultural

Pathology Section, Post

Graduate Institute, Dr. P. D. K.

V., Akola, Maharashtra, India

\section{Dr. PC Pagar}

Assistant Professor of

Agronomy, Agronomy Section,

College of Agriculture

(Dr. P.D.K.V., Akola), Nagpur,

Maharashtra, India

\section{Growth attributes, yield and soil moisture studies of linseed as influenced by different land configuration treatments and irrigation levels}

\author{
RS Marbate, AL Uparkar, RJ Choudhari and Dr. PC Pagar
}

DOI: https://doi.org/10.22271/chemi.2020.v8.i4as.10208

\begin{abstract}
An investigation was undertaken at College of Agriculture, Nagpur to study the effect of land configuration and irrigation levels on growth, yield attributes and yield of linseed during rabi season of 2014-2015 in split plot design with twelve treatment combinations consisting of four land configurations viz., $\mathrm{L}_{1}$ (Flat bed), $\mathrm{L}_{2}$ (Ridges and furrow), $\mathrm{L}_{3}$ (Opening of furrow after two rows) and $\mathrm{L}_{4}$ (Broad bed furrow) and three irrigation levels viz., I1- One irrigation at flowering (40-45 DAS), I2- Two irrigations, one at flowering (40-45 DAS) and second at capsule formation (65-70 DAS) and $\mathrm{I}_{3}$ - Three irrigations, one at vegetative (20-25 DAS), second at flowering (40-45 DAS) and third at capsule formation (65-70 DAS) replicated three times. Linseed variety PKV NL-260 was used as a test crop. The soil was clayey in texture with $\mathrm{p}^{\mathrm{H}} 7.8$ indicating slightly alkaline in reaction. Results showed that application of land configuration treatments significantly increased plant height, number of branches, dry matter accumulation plant ${ }^{-1}(\mathrm{~g})$, seed yield $\left(\mathrm{kg} \mathrm{ha}^{-1}\right)$, straw yield $\left(\mathrm{kg} \mathrm{ha}^{-1}\right)$ and oil content $\left(\mathrm{kg} \mathrm{ha}^{-1}\right)$. Highest values of all the growth characters were recorded in land configuration treatment of broad bed furrow $(\mathrm{BBF})$ but at par with treatment of ridge and furrow. Also seed yield $\left(\mathrm{kg} \mathrm{ha}^{-1}\right)$, straw yield $\left(\mathrm{kg} \mathrm{ha}^{-1}\right)$ and oil yield $\left(\mathrm{kg} \mathrm{ha}^{-1}\right)$ had higher values with BBF but at par with ridge and furrow. Results further revealed that application of three irrigations, one at vegetative stage, second at flowering and third at capsule formation recorded significantly higher values of growth parameters, seed yield $\left(\mathrm{kg} \mathrm{ha}^{-1}\right)$, straw yield $(\mathrm{kg}$ $\left.\mathrm{ha}^{-1}\right)$ and oil yield $\left(\mathrm{kg} \mathrm{ha}^{-1}\right)$ over treatment of one irrigation at flowering and was at par with two irrigations, one at flowering and second at capsule formation.. Higher moisture content was noticed in treatment of broad bed furrow ( $\left.\mathrm{L}_{4}\right)$ among various land configuration treatments. The BBF recorded minimum consumptive use $(105.68 \mathrm{~mm})$. The higher water use efficiency was recorded by BBF $(13.21$

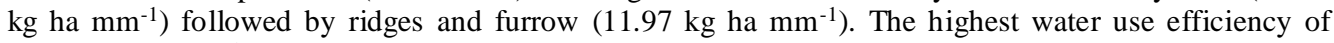
$\left(16.28 \mathrm{~kg} \mathrm{ha} \mathrm{mm}^{-1}\right)$ was recorded in treatment $\left(\mathrm{I}_{3}\right)$. Consumptive use increased to $175.73 \mathrm{~mm}$ when three irrigations were given one at vegetative stage, second at flowering and third at capsule formation.

Interaction effect of land configuration and irrigation levels were found to be non significant in respect of all yield parameters seed and oil yield.
\end{abstract}

Keywords: Yield, land configuration, irrigation levels, yield attributes

\section{Introduction}

Linseed (Linum usitatissimum L.) is an important oilseed crop of central India, locally known as jawas or alsi. It has been grown from ancient time for flax (fiber) and for seed purpose which is rich in oil. Linseed contains high level of lignan and Omega-3 fatty acid possesses anti cancer properties and studies found reduced growth in specific types of tumors. Initial studies suggest benefit individual with certain types of breast and prostate cancer. Linseed is unique among oilseeds as it has high content of Omega-3 fatty acid, alpha linolenic acid (ALA). Linseed contains 35 to $45 \%$ oil with ALA making up about $57 \%$ of the total fatty acids. Omega-3 fatty acids lower levels of triglycerides in blood, thereby reducing heart disease, and also shows promising battle against inflammatory diseases such as rheumatoid arthritis. Linolenic acid (LA), an Omega-6 essential fatty acid is also found in linseed. In India it is grown over an area 468.0 thousand ha which produce about 1.41 lakh tonnes and its cultivation is mostly confined to Madhya Pradesh, Uttar Pradesh, Maharashtra, Bihar and West Bengal. Madhya Pradesh rank first in both area and production among linseed growing states of India. Since, area under linseed is decreased now a day due to less yield hence production technology suitable to its high production needs to be perfected. Increase in crop production
Corresponding Author: RS Marbate

P.G. Students, Agronomy

Section, College of Agriculture,

Nagpur, Maharashtra, India 
can be realized by either extending total area under this crop or by enhancing crop productivity. To ensure high crop productivity, adoption of improved agronomic techniques is essential. Most of the studies indicate that increase in yield is mainly associated with land configuration and irrigation management method. Resorting sowing on land configuration like broad bed and furrow (BBF), ridges and furrow and provision of furrow at regular intervals and reduced tillage are known to help linseed crop during water stress. The proper land configuration is known for increasing moisture intake and resultant yield. The broad bed and furrow acts as drains in high rainfall region and also help in providing more opportunity for in situ soil water conservation. Nalawade and More (1993) reported that, BBF give more pod yield than furrow in every row, furrow after two rows and flat beds. The $\mathrm{BBF}, \mathrm{NBF}$, furrow after two rows gave pod yield of 1.33 , $1.25,1.11 \mathrm{t} \mathrm{ha}^{-1}$, respectively. Excess irrigation causes water logging condition because heavy soils of Vidarbha are poor in drainage. This ultimately affects crop growth and further crop yield. Hence judicious uses of irrigation water become prime importance. Ram Pyare et al. (2005) ${ }^{[10]}$ reported that irrigation at flowering and capsule formation stage enhances grain yield to $4.33 \mathrm{q} \mathrm{ha}^{-1}$ than no irrigation. Therefore, timely irrigation is most important to get high yield from linseed crop. Yenpreddiwar et al. (2007) ${ }^{[14]}$ reported that, irrigation at flowering and capsule filling stages recorded highest yield of $1182 \mathrm{~kg} \mathrm{ha}^{-1}$ than irrigation at flowering stage and no irrigation. Deep black cotton soil having high water holding capacity and stickiness in Nagpur region of Maharashtra state limit the linseed cultivation due to poor drainage. To protect the crop from this hazard and to provide better soil condition for healthy, luxurious proliferation of roots and good response to fertilizer application suitable the present investigation was planned to find out an efficient land configuration method and an optimum irrigation level at which linseed gives maximum growth and seed yield.

\section{Material and Methods}

A field experiment was conducted at Agronomy farm, College of Agriculture, Nagpur during rabi season of 20142015 in split plot design with twelve treatment combinations consisting of four land configurations viz., $\mathrm{L}_{1}$ (Flat bed), $\mathrm{L}_{2}$ (Ridges and furrow), $\mathrm{L}_{3}$ (Opening of furrow after two rows) and $\mathrm{L}_{4}$ (Broad bed furrow) as main plot treatments and three irrigation levels viz., $\mathrm{I}_{1}$ - One irrigation at flowering (40-45 DAS), $\mathrm{I}_{2-}$ Two irrigations, one at flowering (40-45 DAS) and second at capsule formation $(65-70 \mathrm{DAS})$ and $\mathrm{I}_{3-}$ Three irrigations, one at vegetative (20-25 DAS), second at flowering (40- 45 DAS) and third at capsule formation (65-70 DAS) as sub plot treatments replicated three times. The soil of experimental plot was medium in available nitrogen (208.94 $\left.\mathrm{kg} \mathrm{ha}^{-1}\right)$, low in available phosphorus (17.14 $\mathrm{kg} \mathrm{ha}^{-1}$ ), medium in organic carbon $(0.57 \%)$ and very high in available potash (350.42 $\left.\mathrm{kg} \mathrm{ha}^{-1}\right)$ as regards to fertility status and slightly alkaline in reaction ( $\mathrm{pH} 7.8)$. The soil of the experimental field was clayey in texture. The crop variety PKV NL-260 was used with row to row spacing of $45 \mathrm{~cm}$. Gross plot size was $4.05 \mathrm{~m} \times 4.2 \mathrm{~m}$ and net plot size was $3.15 \mathrm{~m} \times 3.8 \mathrm{~m}$. The distance between two replications was $1.50 \mathrm{~m}$ and $1 \mathrm{~m}$ between two plots. Full dose of phosphorus and half dose of nitrogen were applied at sowing and remaining half dose of $\mathrm{N}$ was applied at 30 DAS.

The moisture percentage was calculated on oven dry basis by using following formula.

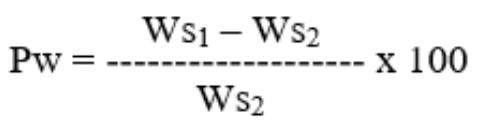

Where,

$\mathrm{Pw}=$ Moisture percentage on oven dry basis

$\mathrm{Ws}_{1}=$ Fresh weight of soil

$\mathrm{Ws}_{2}=$ Dry weight of soil

Consumptive use of water under each irrigation treatment was calculated by considering following components.

1. The potential evapo-transpiration during the period of 72 hours after each irrigation.

2. Soil moisture depletion by crop from $0-30 \mathrm{~cm}$ depth of soil profile during period between two irrigations.

3. Effective rainfall during the interval between irrigations. Consumptive use was estimated by use of following formula

$$
C u=\sum_{K=1}^{N} E K \times 0.08+\sum_{i=1}^{n} \frac{(M a i-M b i)}{100} \times \text { Asi } x D i+E R
$$

Where

$\mathrm{Cu}=$ Consumptive use of water in $\mathrm{mm}$

$\mathrm{EK}=$ Actual evaporation for the period of 72 hours immediately after $\mathrm{K}^{\text {th }}$ irrigation from USWB class A

open pan evapometer.

$0.8=$ Crop coefficient

$\mathrm{N}=$ Number of times

Mai $=$ Soil moisture after irrigation in per cent

$\mathrm{Mbi}=$ Soil moisture before irrigation in per cent

$\mathrm{N}=$ Number of soil layers

Asi $=$ Bulk density of the $i^{\text {th }}$ layer $\left(\mathrm{gm} / \mathrm{cm}^{3}\right)$

$\mathrm{Di}=$ Soil depth of the $\mathrm{i}^{\text {th }}$ layer $(\mathrm{mm})$

$\Sigma=$ Summation of

$\mathrm{ER}=$ Effective rainfall

As the water table was more than seven meters, ground water contribution was not taken into account.

Thus consumptive use during the given irrigation interval was worked out by adding all the above components together and all such consumptive use figures were added together to get the total consumptive use during the season of the crop.

Water use efficiency was calculated in different treatments on the basis of seed yield and consumptive use of water in a given treatment. It is the amount of seed yield per unit of consumptive use. The formula for water use efficiency is follows.

\section{$\mathrm{WUE}=\frac{\mathrm{Y}}{\mathrm{ET}}$}

Where,

WUE = Water use efficiency in $\mathrm{kg}$ ha $\mathrm{mm}-1$

$\mathrm{Y}=$ Economic yield in $\mathrm{kg} / \mathrm{ha}$

$\mathrm{ET}=$ Total evapo-transpiration in $\mathrm{mm}$

At the time of harvesting, Plant height $(\mathrm{cm})$, No. of branches plant $^{-1}$, Dry matter plant ${ }^{-1}(\mathrm{~g})$, seed yield $\left(\mathrm{kg} \mathrm{ha}^{-1}\right)$, straw yield $\left(\mathrm{kg} \mathrm{ha}^{-1}\right)$, Oil yield $\left(\mathrm{q} \mathrm{ha}^{-1}\right)$, moisture content $(\%)$ at $0-30 \mathrm{~cm}$ depth, Consumptive use $(\mathrm{mm})$ and Water use efficiency $(\mathrm{kg}$ ha $\mathrm{mm}^{-1}$ ) were recorded. In order to represent the plot, five plants of linseed from each net plot were selected randomly for various biometric observations on post harvest studies. 
The selected five plants were labeled and all biometric observations were recorded properly on them.

\section{Results and Discussion}

\section{Effect on growth attributes}

The data pertaining to plant height $(\mathrm{cm})$, No. of branches plant $^{-1}$ and Dry matter plant ${ }^{-1}(\mathrm{~g})$ as influenced by various treatments are presented in Table 1 .

\section{Effect of Land configuration}

The data revealed that, plant height $(\mathrm{cm})$, No. of branches plant $^{-1}$ and Dry matter plant ${ }^{-1}(\mathrm{~g})$ were significantly maximum in BBF over flat bed but it was at par with ridges and furrow at all growth stages. Significant increase in these attributes with broad bed furrow and ridges and furrow indicated adequate moisture conservation in soil, which had been benefited to the crop during growth period, resulted in optimum cell division and their elongation which enhanced plant height.

These results are in confirmity with the findings of Patil et al. (2011) ${ }^{[7]}$, Vaghasia et al. (2007) ${ }^{[12]}$ and Lakhera (2008) ${ }^{[6]}$.

\section{Irrigation levels}

Irrigation levels had significant influence on plant height (cm), No. of branches plant ${ }^{-1}$ and Dry matter plant ${ }^{-1}(\mathrm{~g})$ at all stages of crop growth. The plant height, No. of branches plant $^{-1}$ and Dry matter plant ${ }^{-1}(\mathrm{~g})$ were significantly more in $\mathrm{I}_{3}$ - three irrigations, one at vegetative stage, second at flowering and third at capsule formation over flat bed but it was at par with $\mathrm{I}_{2}$ - two irrigations, one at flowering and second at capsule formation at harvest. Similar results were reported by Yenpreddiwar (2006) ${ }^{[13]}$, Chauhan et al. (2008) ${ }^{[2]}$ and Ram-Pyare et al. $(2005)^{[10]}$.

\section{Interaction}

Interaction effects of land configuration and irrigation levels were non-significant.

\section{Effect on seed and oil yield}

Data regarding mean seed yield $\left(\mathrm{q} \mathrm{ha} \mathrm{h}^{-1}\right)$, straw yield $\left(\mathrm{q} \mathrm{ha} \mathrm{h}^{-1}\right)$ and oil yield $\left(\mathrm{q} \mathrm{ha}^{-1}\right)$ as influenced by different treatments are presented in table 1 .

\section{Effect of Land configuration}

Seed yield ha ${ }^{-1}$, straw yield $\left(\mathrm{q} \mathrm{ha}^{-1}\right)$ and oil yield $\left(\mathrm{q} \mathrm{ha}^{-1}\right)$ were significantly influenced due to various land configuration treatments. The land configuration treatment of BBF being at par with ridges and furrows showed significant increase in seed yield $\left(\mathrm{q} \mathrm{ha}{ }^{-1}\right)$, straw yield $\left(\mathrm{q} \mathrm{ha} \mathrm{h}^{-1}\right)$ and oil yield $\left(\mathrm{q} \mathrm{ha} \mathrm{h}^{-1}\right)$ over flat bed and furrow after two rows. It is a well known fact that, land configuration treatments helps in moisture conservation and providing good drainages which might be the reasons in producing more yields in these treatments. Similar effects of modified land configuration have also been reported by Kantwa et al. (2005) ${ }^{[5]}$ and Paul (2014) ${ }^{[9]}$.

\section{Effect of Irrigation levels}

Seed yield ha $\mathrm{h}^{-1}$, straw yield $\left(\mathrm{q} \mathrm{ha}^{-1}\right)$ and oil yield $\left(\mathrm{q} \mathrm{ha}^{-1}\right)$ were significantly influenced due to irrigation levels. Seed yield was maximum in application of $\left(\mathrm{I}_{3}\right)$ three irrigations $(13.64 \mathrm{q}$ $\left.\mathrm{ha}^{-1}\right)$, one at vegetative stage, second at flowering and third at capsule formation which were at par with $\left(\mathrm{I}_{2}\right)$ two irrigations $\left(13.0 \mathrm{q} \mathrm{ha}^{-1}\right)$, one a flowering and second at capsule formation and significantly superior over $\left(\mathrm{I}_{1}\right)$ one irrigation at flowering. This clearly indicated availability of moisture increased vigour and growth of crop which helped in improving the yield components and consequently yield. These findings are in close accordance with Yenpreddiwar et al. (2007) ${ }^{[14]}$, Jaiswal (2014) ${ }^{[4]}$, Ram-Pyare et al. (2005) ${ }^{[10]}$ and Chormule and Datonde (2001).

\section{Interaction effect}

Interaction effect was found to be non significant.

\section{Effect on Soil moisture studies}

The data in respect of moisture content (\%) at $30 \mathrm{~cm}$ depth, Consumptive use $(\mathrm{mm})$ and Water use efficiency $\left(\mathrm{kg}\right.$ ha $\mathrm{mm}^{-}$ ${ }^{1}$ ) was given in Table 1 .

Table 1: Growth Attributes, Yield and Soil Moisture Studies of Linseed As Influenced By Different Land Configuration Treatments and Irrigation Levels

\begin{tabular}{|c|c|c|c|c|c|c|c|c|c|}
\hline Treatments & \multicolumn{3}{|c|}{ Growth attributes } & \multicolumn{3}{|c|}{ Yield } & \multicolumn{3}{|c|}{ Soil moisture studies } \\
\hline Land configuration & $\begin{array}{c}\text { Plant } \\
\text { height } \\
\text { (cm) }\end{array}$ & $\begin{array}{c}\text { No. of } \\
\text { branches } \\
\text { plant }^{-1}\end{array}$ & $\begin{array}{l}\text { Dry matter } \\
\text { plant }^{-1}(g)\end{array}$ & $\begin{array}{c}\text { Seed Yield } \\
\left(\mathrm{q} \mathrm{ha} \mathbf{1}^{-1}\right)\end{array}$ & $\begin{array}{c}\text { Straw } \\
\text { Yield (q } \\
\left.\text { ha }^{-1}\right)\end{array}$ & $\begin{array}{c}\text { Oil yield } \\
\left(\mathbf{q} \mathbf{h a}^{-1}\right)\end{array}$ & $\begin{array}{c}\text { Moisture } \\
\text { content }(\%) \text { at } \\
0-30 \mathrm{~cm} \text { depth }\end{array}$ & $\begin{array}{c}\text { Consumptive } \\
\text { use (mm) }\end{array}$ & $\begin{array}{c}\text { Water use } \\
\text { efficiency } \\
\left(\mathrm{kg} \mathrm{ha} \mathrm{mm}^{-1}\right)\end{array}$ \\
\hline L1- Flat bed & 43.70 & 3.33 & 3.01 & 11.18 & 13.92 & 4.26 & 19.7 & 114.89 & 9.73 \\
\hline L2- Ridges and furrow & 46.15 & 3.66 & 3.37 & 13.15 & 14.89 & 5.07 & 21.1 & 109.77 & 11.97 \\
\hline L3- Furrow after two rows & 45.06 & 3.50 & 3.25 & 12.67 & 14.02 & 4.86 & 19.9 & 114.73 & 11.04 \\
\hline $\mathrm{L}_{4}-\mathrm{BBF}$ & 47.90 & 3.89 & 3.74 & 13.97 & 17.15 & 5.42 & 22.3 & 105.68 & 13.21 \\
\hline $\mathrm{SE}(\mathrm{m}) \pm$ & 0.80 & 0.07 & 0.11 & 0.34 & 0.66 & 0.14 & - & - & - \\
\hline $\mathrm{CD}$ at $5 \%$ & 2.78 & 0.26 & 0.39 & 1.19 & 2.30 & 0.51 & - & - & - \\
\hline \multicolumn{10}{|c|}{ Irrigation levels } \\
\hline $\mathrm{I}_{1}$ - One irrigation & 43.56 & 2.86 & 3.00 & 11.58 & 13.24 & 4.38 & 19.9 & 71.10 & 7.76 \\
\hline $\mathrm{I}_{2}$ - Two irrigations & 46.36 & 3.96 & 3.48 & 13.00 & 15.54 & 5.01 & 20.3 & 95.5 & 13.61 \\
\hline I3- Three irrigations & 48.23 & 4.42 & 3.54 & 13.64 & 17.00 & 5.32 & 21.1 & 175.73 & 16.28 \\
\hline $\mathrm{SE}(\mathrm{m}) \pm$ & 0.75 & 0.17 & 0.12 & 0.22 & 0.50 & 0.10 & - & - & - \\
\hline $\mathrm{CD}$ at $5 \%$ & 2.26 & 0.52 & 0.37 & 0.66 & 1.50 & 0.30 & & - & - \\
\hline \multicolumn{10}{|c|}{ Interaction } \\
\hline $\mathrm{SE}(\mathrm{m}) \pm$ & 1.51 & 0.35 & 0.25 & 0.44 & 1.00 & 0.20 & - & - & - \\
\hline $\mathrm{C} \mathrm{D}$ at $5 \%$ & N.S. & N.S. & N.S. & N.S. & N.S. & N.S. & - & - & - \\
\hline
\end{tabular}

\section{Effect of Land configuration}

Land configuration did not show much variation in moisture content $(\%)$ of soil at various intervals throughout the crop growth period and at harvest. Higher moisture content was noticed in treatment of broad bed furrow $\left(\mathrm{L}_{4}\right)$ among various 
land configuration treatments. These findings are in close accordance with Suryawanshi et al. (2008) ${ }^{[11]}$.

The flat bed recorded maximum consumptive use (114.89) followed by furrow after two rows $(114.73 \mathrm{~mm})$ and ridges and furrow $(109.77 \mathrm{~mm})$. The $\mathrm{BBF}$ recorded minimum consumptive use $(105.68 \mathrm{~mm})$. These findings are in close accordance with Patil et al. (2011) ${ }^{[7]}$. The higher water use efficiency was recorded by BBF $\left(13.21 \mathrm{~kg}^{\mathrm{g}} \mathrm{mm}^{-1}\right)$ followed

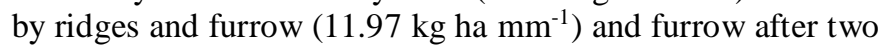
rows $\left(11.04 \mathrm{~kg} \mathrm{ha} \mathrm{mm}^{-1}\right)$. The lowest water use efficiency was recorded by flat bed treatment $\left(9.73 \mathrm{~kg}\right.$ ha $\left.\mathrm{mm}^{-1}\right)$. These findings are in close accordance with Suryawanshi et al. $(2008)^{[11]}$.

\section{Effect of Irrigation levels}

The irrigation levels also did not show much variation in moisture due to various irrigation levels. However, maximum values were observed in treatment of three irrigations, one at vegetative stage, second at flowering and third at capsule formation $\left(\mathrm{I}_{3}\right)$ among the other irrigation levels. These findings are in close accordance with Jaiswal (2014) ${ }^{[4]}$.

The lowest consumptive use of $71.10 \mathrm{~mm}$ recorded with one irrigation $\left(\mathrm{I}_{1}\right)$. With two irrigations, one at flowering and second at capsule formation the consumptive use was 95.50 $\mathrm{mm}$, when three irrigations were given one at vegetative stage, second at flowering and third at capsule formation the consumptive use increased to $175.73 \mathrm{~mm}$. These results are in tune with the findings reported by Yenpreddiwar (2006) ${ }^{[13]}$. The highest water use efficiency of $\left(16.28 \mathrm{~kg} \mathrm{ha} \mathrm{mm}^{-1}\right)$ was recorded in treatment $\left(\mathrm{I}_{3}\right)$ one at vegetative stage, second at flowering and third at capsule formation followed by in $\left(\mathrm{I}_{2}\right)$ two irrigations, one at flowering and second at capsule formation $\left(13.61 \mathrm{~kg}\right.$ ha $\left.\mathrm{mm}^{-1}\right)$. These findings are in close accordance with Patil et al. (2011) ${ }^{[7]}$.

\section{References}

1. Anonymous. District socio-economic Review, 2013-14. Directorate of economic and statistic, Government of Maharashtra, 2014.

2. Chauhan DVS, Lodhi MD, Neeraj Kumar Verma. Effect of sowing dates, varieties and number of irrigations on yield attributes, yield and quality of linseed under bundelkhand condition of Uttar Pradesh. Agric. Sci. Digest. 2008; 28(4):271-273.

3. Datonde BN, Vyas JS. Response of safflower to irrigation level, land configuration and wheat straw mulch, P.K.V. Res. J. 2003; 27(1):77-78.

4. Jaiswal SG. Effect of irrigation layout and irrigation levels on growth and yield of mustard. M.Sc. (Agri.) Thesis (unpub) Dr. P.D.K.V., Akola, 2014.

5. Kantwa SR, Ahlawat IPS, Gangaiach B. Effect of land configuration, post monsoon irrigation and phosphorus on performance of sole and inter cropped pigeonpea. Indian J. Agron. 2005; 50(4):278-280.

6. Lakhera Vishnuprakash. Effect of land configuration and nutrient management on productivity of soybean (Glycine max). M.Sc. (Agri) Thesis (unpbu), Dr. P.D.K.V., Akola, 2008.

7. Patil DB, Mendhe SN, Kolte HS, Sathe HD. Effect of land configuration and irrigation management on yield attributes and economics of linseed. Journal of Soils and Crops. 2011; 21(1):86-89.

8. Patil MR. Influence of nutrient management and land layouts on growth and yield of soybean, M.Sc. Thesis (unpub) Dr. P.D.K.V., Akola, 2005.
9. Paul SA. Effect of land configuration and nutrient management on productivity of irrigated linseed. M.Sc. (Agri.) Thesis (unpub) Dr. P.D.K.V., Akola, 2014.

10. Ram-Pyare RPS, Kedar-Prasad, Yadav SL. Effect of second irrigation based on cumulative pan evaporation on yield. Farm-sci-J. 2005; 14(2):40-42.

11. Suryawanshi MW, Jadhav GS, Jadhav PD, Jagtap PB. Influence of land layouts and irrigation schedules on yield and water yield response function of groundnut. J. Soils and Crops. 2008; 18(1):112-116.

12. Vaghasia PM, Khanopara VD, Matnukia RK. Effect of in situ moisture conservation and sulphur nutrition on yield quality and nutrients uptake by groundnut. J Agric. Sci. 2007; 3(1):151-153.

13. Yenpreddiwar MD. Effect of irrigation and moisture conservation practices on growth, yield and quality of linseed. M.Sc. Thesis submitted to Dr. P.D.K.V., Akola, 2006.

14. Yenprediwar MD, Nikam RR, Dange RB, Gaidhane SN. Water use studies in linseed as influenced by different irrigation levels and moisture conservation practices. $\mathrm{J}$ of Soil and Crops. 2007; 17(1):176-177. 